\title{
Effect of rearing temperature and hormone treatment on sex ratio, survival and body weight of Oreochromis niloticus fry
}

\author{
Magdy A. Soltan ${ }^{1}$; Mohamed S. Hassaan ${ }^{2}$; Gamal O. El-Nagaar ${ }^{3}$ and Wahead E. \\ Mohammed $^{3}$ \\ 1- Faculty of Agriculture, Banha University. \\ 2- National Institute of Oceanography and Fisheries, Cairo, Egypt. \\ 3- World Fish Center, Abbassa, Abou Hammad, Sharkia, Egypt.
}

\section{ABSTRACT}

The present experiment was carried out to investigate the effect of rearing water temperature in combination with or without hormone application on masculinization of newly hatched O. niloticus fry. Nile tilapia fry $(0.025 \mathrm{~g})$ were reared in three levels of temperature 25,30 and $35^{\circ} \mathrm{C}$ and in each rearing temperature fry were fed diet with or without supplementation of $60 \mathrm{mg} 17 \alpha$-methyltestosterone (MT) for 7, 14, 21 and 28 days.

O. niloticus fry fed diet without MT and reared at different water temperature 25,30 and $35^{\circ} \mathrm{C}$ significantly increased the male ratio from 48.67 to 48.67 and $65.33 \%$ after one week; 48.67 to 64.00 and $72.67 \%$ after two weeks; 48.67 to 68.67 and $77.33 \%$ after three weeks and 48.67 to 80.67 and $84.00 \%$ after four weeks, respectively. While fry fed diet supplemented with MT with increasing rearing water temperature from 25 to 30 or $35^{\circ} \mathrm{C}$ significantly increased male percentage from 58.00 to 84.67 and $86.00 \%$ after one week; 67.66 to 93.33 and $96.67 \%$ after two weeks; 79.00 to 97.33 and $98.67 \%$ after three weeks and 85.67 to 98.00 and $99.33 \%$ after four weeks.

Mortality rate for $O$. niloticus fry reared at different water temperature 25,30 and fed diet without MT significantly increased from 10.33 to 14.00 and $14.33 \%$ after one week; 10.33 to 15.33 and $15.00 \%$ after two weeks; 10.33 to 15.33 and $15.17 \%$ after three weeks and 10.33 to 15.83 and $16.83 \%$ after four weeks. But, supplementation of O. niloticus feed diet supplemented with MT and increasing rearing water temperature from to 30 or $35^{\circ} \mathrm{C}$ significantly increased mortality rate from 14.67 and $14.00 \%$ after one week; 16.00 and $15.67 \%$ after two weeks; 15.33 and $15.67 \%$ after three weeks and 16.00 and $17.33 \%$ after four weeks of treatment.

The highest fry body weight was recorded for fry group administrated with MT and reared at water temperature of $35^{\circ} \mathrm{C}$ and the opposite trend was observed with fry group reared at the lower temperature $\left(25^{\circ} \mathrm{C}\right)$ and fed diet without MT.

Keywords: Temperature, hormone treatment, sex ratio, Oreochromis niloticus

\section{INTRODUCTION}

Tilapias (Oreochromis niloticus) are a paradox in reproduction. The relative fecundity of $O$. niloticus species is low; 6,000-13,000 eggs/ $/ \mathrm{kg} / \mathrm{spawn}$. However, this is compensated by high survival rate and its iteroparity nature. Ideally, a fish species used in aquaculture is not allowed to reproduce in the culture environment before reaching market size. This phenomenon presents a significant challenge to the fish culturist. Most tilapia species often reach maturity within 6-8 months of hatching at a size often less than $100 \mathrm{~g}$. Under favourable conditions tilapia will start to reproduce 
leading to intraspecific competition hence stunted growth and become unmarketable (Beaven and Muposhi 2012).

All male culture of tilapia is preferred because of their fast growth. Several techniques have been used to produce monosex tilapia to control; unwanted reproduction and among these include; manual sexing (Guerrero, 1982); genetic manipulation (Pandian and Varadaraj 1988); and sex reversal through sex oestrogenic hormone administration (Guerrero, 1982).

Hormone treatment does not alter the genotype of the fish but directs the expression of the phenotype. Production of all male population through administration of androgen (17 $\alpha-\mathrm{MT})$ is considered to be the most effective and economically feasible method for obtaining all male tilapia populations (Guerrero and Guerrero 1988). Recently hatched tilapia fry do not have developed gonads such that it is possible to intervene at this early point in the life history and direct gonadal development to produce monosex populations. Exogenous steroids given during the gonadal development period can control the phenotype overriding the expression of the genotypically determined sex.

Some studies provided evidence that water temperature also governed the phenotypic sex of Oreochromis spp. A vast majority of experiments demonstrated that high temperatures favoured the production of (almost) monosex male progenies $(O$. niloticus: Baroiller et al., 1995: 1996 a \& b; O. aureus: Baras et al., 2000). Except for some strains (Trewavas, 1983 ), $36-37^{\circ} \mathrm{C}$ is close to the upper incipient lethal temperature of Nile tilapia (Balarin and Hatton, 1979), and above the thermal optimum for its growth (Melard, 1986).

Therefore this study aimed to (i) measure the sex ratio and survival of progenies of Nile tilapia reared at different temperatures during their early life stages; (ii) measure the sex ratio and survival of progenies of Nile tilapia fed the diet supplemented or did not supplemented by $17 \alpha$-MT (iii) measure the effect of interaction between thermal and hormonal treatments on sex ratio and survival of progenies of Nile tilapia.

\section{MATERIALS AND METHODS}

The present experiment was carried out at the hatchery unit of the experimental station of the World Fish Center, Abbassa, Abou-Hammad, Sharkia, Egypt to investigate the effect of rearing water temperature in combination with or without hormone application for different periods $(1,2,3$ and 4 weeks) on masculinization of newly hatched tilapia fry.

\section{Broodstock and fry collection:}

Oreochromis niloticus broodstock were brought from the same experimental station and stocked at a sex ratio of 3 female: 1 male in concrete tanks of $12 \mathrm{~m}^{3}$ filled with filtered canal water from Ismailia canal to maintain a water depth of seventy (70) $\mathrm{cm}$ and supplied with compressed air through air diffusers to assure maintaining near optimum dissolved oxygen levels in the tank water.

Spawning tanks were monitored daily to collect any hatched fry using fine nets to undergo the experiment. Tanks were covered with plastic sheets ( $2 \mathrm{~mm}$ thickness) extended over a metallic frame of arched iron bars similar to those used in agricultural greenhouses.

\section{Experimental design:}

Three aquaria of 80 liters each were filled with water and used for each treatment. 300 hatched tilapia fry $(0.025 \mathrm{~g})$ were placed in each aquarium. All aquaria 
were supplied with the specific diet (45\% crude protein) with or without supplementation of $17 \alpha$-methyl testosterone (MT) at $60 \mathrm{mg} / \mathrm{kg}$ diet. Feeding rate was $15 \%$ of the biomass of each aquarium divided into 5 meals per day. Tilapia fry were randomly distributed into 6 treatments as follows:

T1: $\mathrm{C} 25 \mathrm{H} 0$ fry reared at $25^{\circ} \mathrm{C}$ and fed MT free diet.

T2: $\mathrm{C} 25 \mathrm{H} 1$ fry reared at $25^{\circ} \mathrm{C}$ and fed MT supplemented diet.

T3: $\mathrm{C} 30 \mathrm{H} 0$ fry reared at $30^{\circ} \mathrm{C}$ and fed MT free diet.

T4: $\mathrm{C} 30 \mathrm{H} 1$ fry reared at $30^{\circ} \mathrm{C}$ and fed MT supplemented diet.

T5: $\mathrm{C} 35 \mathrm{H} 0$ fry reared at $35^{\circ} \mathrm{C}$ and fed MT free diet.

T6: $\mathrm{C} 35 \mathrm{H} 1$ fry reared at $35^{\circ} \mathrm{C}$ and fed MT supplemented diet

\section{Diets preparation:}

The hormone treated feed was prepared as described by (Killian and Kohler, 1991). The MT used in the present study was obtained from the Sigma Chemicals Ltd. A stock solution was made by dissolving $1 \mathrm{~g}$ of hormone in $1 \mathrm{~L}$ of $95 \%$ ethanol. Treatments were made by taking the accurate amount of the hormone from stock solution and brought up to $100 \mathrm{ml}$ by addition $95 \%$ ethanol. This solution was evenly sprayed over $1 \mathrm{~kg}$ of the diet mixure (Table 1). The mixture was mixed again and this was repeated to ensure an equal distribution of the MT throughout the feed. Treated diets were fan dried in shade at $25^{\circ} \mathrm{C}$ for 24 hours then kept in freezer till use.

Table 1: Formulation and composition of the artificial diet used for O. niloticus fry

\begin{tabular}{|l|c|}
\hline Ingredients & $\%$ \\
\hline Fish meal & 38 \\
\hline Soy bean meal & 30 \\
\hline Yellow corn & 23 \\
\hline Bran & 3.5 \\
\hline Vegetable oil & 3 \\
\hline vitamins\&minerals mixture $^{1}$ & 2.2 \\
\hline Ascorbic acid & 0.3 \\
\hline Sum & 100 \\
\hline Crude protein & 44.65 \\
\hline Metabolizable energy (Kcal/kg feed) & 2895 \\
\hline P/E ratio (mg ptotein/kcal) & 154.22 \\
\hline
\end{tabular}

${ }^{1}$ Vitamin \& mineral mixture/kg premix : Vitamin $\mathrm{D}_{3}, 0.8$ million IU; A, 4.8 million IU; E, $4 \mathrm{~g} ; \mathrm{K}$, $0.8 \mathrm{~g}$; B1, 0.4 g; Riboflavin, 1.6 g; B6, 0.6 g, B12, 4 mg; Pantothenic acid, 4 g; Nicotinic acid, 8 g; Folic acid, 0.4 g Biotin, 20 mg , Mn, 22 g; Zn, 22 g; Fe, 12 g; Cu, 4 g; I, 0.4 g, Selenium, 0.4 g and Co, $4.8 \mathrm{mg}$.

\section{Flow pattern:}

All treatments aquaria were placed in a wet lab where a water recycling unit was used to supply the aquaria with temperature controlled water. In order to control water temperature in the lab, this experiment was conducted on three separate stages $(25,30$ and $35^{\circ} \mathrm{C}$ ). Each part the effluent water of the glass rearing tanks was passed through heater. After that, water passes through the filter unit before it was returned to the fish tank by pump. Daily partial water was added per day to reduce the accumulation of nitrate and substitute the water losses due to the evaporation. During the experimental period continuous monitoring and recording of the main water quality parameters took place and outlined in Table (2). 
Table 2: Ammonia, dissolved oxygen and temperature after 1, 2, 3 and 4 weeks of different heat treatments 25,30 and $35^{\circ} \mathrm{C}$.

\begin{tabular}{|l|l|c|c|c|c|}
\hline \multirow{3}{*}{ Temperature } & \multirow{2}{*}{ Parameter } & \multicolumn{4}{|c|}{ Experimental periods } \\
\cline { 3 - 6 } & & $1^{\text {st }}$ week & $2^{\text {nd }}$ week & $3^{\text {rd }}$ week & $4^{\text {th }}$ week \\
\hline \multirow{3}{*}{$25^{\circ} \mathrm{C}$} & Ammonia & 0.2 & 0.4 & 0.3 & 0.5 \\
\cline { 2 - 6 } & Dissolved oxygen & 6.88 & 6.89 & 7.00 & 6.33 \\
\cline { 2 - 6 } & Temperature & 25.6 & 25.2 & 25.00 & 25.40 \\
\hline \multirow{3}{*}{$30^{\circ} \mathrm{C}$} & Ammonia & 0.5 & 0 & 0.43 & 0.4 \\
\cline { 2 - 6 } & Dissolved oxygen & 7.1 & 6.88 & 6.17 & 7.8 \\
\cline { 2 - 6 } & Temperature & 30.1 & 30.55 & 30.2 & 30.4 \\
\hline \multirow{3}{*}{$35^{\circ} \mathrm{C}$} & Ammonia & 0.4 & 0.2 & 0.5 & 0.3 \\
\cline { 2 - 6 } & Dissolved oxygen & 6.86 & 7.2 & 6.46 & 7.1 \\
\cline { 2 - 6 } & Temperature & 35 & 35.2 & 35.4 & 34.6 \\
\hline
\end{tabular}

Means followed by different letters in each column for each treat for each trait significantly different $(\mathrm{P}<0.05)$.

\section{Phenotypic sex determination (Squash Technique):}

After each mentioned period for each treatment, a sample of 25 fry was collected from each aquarium to undergo sex ratio check using the squash technique.

Trinocular microscope with camera and monitor (Boeco Germany) were used to examine the gonads. Aceto-carmine solution was prepared according to Guerrero and Shelton (1974) where $0.5 \mathrm{~g}$ of indigo carmine was added to $100 \mathrm{ml}$ of acetic acid $(45 \%)$ and boiled for 5 minutes. After cooling, the solution was filtered using filter paper and transferred to a dark bottle. Bouin's solution was prepared according to Clark (1981). A stock Alcoholic Bouin's Solution was prepared by mixing $750 \mathrm{ml}$ ethanol alcohol $80 \%$ and $300 \mathrm{ml}$ formaldehyde and $5 \mathrm{gm}$ picric acid and this solution was well mixed and the working solution formed from $70 \mathrm{ml}$ stock solution $+5 \mathrm{ml}$ acetic acid. Acetic acid was added before use.

Fish samples were killed by cold shock (water temperature of $0^{\circ} \mathrm{C}$ ), weighed, measured, and dissected. For microscopic examination (Squash Technique) fish were cut ventrally, using a scalpel, from the genital papilla to the base of the pectoral fin. A window on the lateral side was opened and the viscera were removed, leaving gonads, swim bladder and kidneys in place. A few drops of Bouin's solution were applied topically to the gonads. This procedure hardened the gonadal tissue facilitating its removal. The anterior and posterior ligaments were cut, and both gonads were removed using a forceps and placed on a glass slide. Aceto-carmine solution was added and the tissue was covered with a cover slip. Both gonads were then examined over their entire length under a compound microscope using magnifications of $100 \times$ and $400 \times$.

Statistical analysis:

Statistical analysis of the obtained data was analyzed according to SAS (1996). Differences between means were tested for significance according to Duncan's multiple rang test as described by Duncan (1955).

\section{RESULTS AND DISCUSSION}

\section{Sex ratio}

The first fish group (C25H0) showed the lowest male percentage (48.67\%) for the different rearing periods, 1, 2, 3 or 4 weeks (Table 3). After one week of treatment, the third fish group $(\mathrm{C} 30 \mathrm{H} 0)$ showed the same male population as control $(\mathrm{C} 25 \mathrm{H} 0)$ group $(48.67 \%)$ while the successive treatment periods $(2,3$ or 4 weeks of treatment) showed higher male percentages (64.00, 68.67 and $80.67 \%$, respectively) 
and the same trend was also observed for the $\mathrm{C} 30 \mathrm{H} 0$ group indicating that the positive effect of rearing water temperature begin after two weeks at least. This also demonstrated that the temperatures used in treatments were sufficient to induce the sex reversal because there was change in the proportion of males in these groops.

Table 3: Sex ratio of $O$. niloticus fry reared in different water temperature and fed diet with or without $17 \alpha$-MT for four weeks.

\begin{tabular}{|l|c|c|c|c|}
\hline \multirow{2}{*}{ Treatments } & \multicolumn{4}{|c|}{ Duration of treatments (week) } \\
\cline { 2 - 5 } & 1 & 2 & 3 & 4 \\
\hline $\mathrm{C} 25 \mathrm{H} 0$ & $48.67 \mathrm{~d}$ & $48.67 \mathrm{~d}$ & $48.67 \mathrm{~d}$ & $48.67 \mathrm{~d}$ \\
\hline $\mathrm{C} 25 \mathrm{H} 1$ & $58.00 \mathrm{c}$ & $67.00 \mathrm{c}$ & $79.00 \mathrm{~b}$ & $85.67 \mathrm{~b}$ \\
\hline $\mathrm{C} 30 \mathrm{H} 0$ & $48.67 \mathrm{~d}$ & $64.00 \mathrm{c}$ & $68.67 \mathrm{c}$ & $80.67 \mathrm{c}$ \\
\hline $\mathrm{C} 30 \mathrm{H} 1$ & $84.67 \mathrm{a}$ & $93.33 \mathrm{a}$ & $97.33 \mathrm{a}$ & $98.00 \mathrm{a}$ \\
\hline $\mathrm{C} 35 \mathrm{H} 0$ & $65.33 \mathrm{~b}$ & $72.67 \mathrm{~b}$ & $77.33 \mathrm{~b}$ & $84.00 \mathrm{bc}$ \\
\hline $\mathrm{C} 35 \mathrm{H} 1$ & $86.00 \mathrm{a}$ & $96.67 \mathrm{a}$ & $98.67 \mathrm{a}$ & $99.33 \mathrm{a}$ \\
\hline $\mathrm{SE}$ & \pm 1.97 & \pm 1.56 & \pm 1.47 & \pm 1.43 \\
\hline
\end{tabular}

Means followed by different letters in each column for each treat for each trait significantly different $(\mathrm{P}<0.05)$.

After the first week of treatment, the $6^{\text {th }}$ fish group $(\mathrm{C} 35 \mathrm{H} 1)$ showed the highest significant $(\mathrm{P}<0.001)$ male population $(86.00 \%)$ compared the other fish groups. Male percentage increased to $96.67,98.67$ and $99.33 \%$ after 2,3 and 4 weeks of treatment, respectively and relativelly similar results was also obtained for $\mathrm{C} 30 \mathrm{H} 1$ group indicating the high efficiency of $17 \alpha-\mathrm{MT}$ adminstration on sex reversal of $O$. niloticus.

The highest male percentages were obtained with the $6^{\text {th }}$ fish group $(\mathrm{C} 35 \mathrm{H} 1)$ which did not significantly different from that recorded by the $4^{\text {th }}$ fish group $(\mathrm{C} 30 \mathrm{H} 1)$ after 1, 2, 3 and 4 weeks from the treatment start.

Generally, the obtained results in the present study indicated that, supplementation of $O$. niloticus fry with $60 \mathrm{mg} 17 \alpha-\mathrm{MT} / \mathrm{kg}$ feed with increasing rearing water temperature from 25 to 30 or $35^{\circ} \mathrm{C}$ significantly increased male percentage to 84.67 and $86.00 \%$ after one week; 93.33 and $96.67 \%$ after two weeks; 97.33 and $98.67 \%$ after three weeks and 98.00 and $99.33 \%$ after four weeks of treatment.

Producing a monosex population of $O$. niloticus for aquaculture is high priority since males have a higher growth rate as compared to females. In this study, we observed a relatively high male percentage compared to those not subjected to the hormone. These results in terms of male to female percentage are similar to other findings of Beaven and Muposhi (2012) who showed that O. niloticus fry fed to a diet treated with $17 \alpha$-MT had a significantly high male population (90.06) as compared to those fed to a non hormone treated diet $(50.63 \%)$.

The high male percentage in the different groups found in the present experiment cannot be attributed to differentially higher mortality of the females as suggested by Mair et al., (1990), but to the hormone treatment given that high rates of survival were obtained and that there were no significant differences in survival among treated and control fry.

Hormonal treatments are very efficient, but they could pose environmental problems in the future, due to uncontrolled discharge of the resulting waste water (i.e. steroids and/or metabolites are not removed from the water before discharge).

We noticed that ambient water temperature during the period of sex differentiation of fry strongly influences sex ratio in Nile tilapia (O. niloticus), as shown by Baroiller et al., (1995, 1996a and Tessema et al., 2006) on O. niloticus (strain 
Bouake), Baroiller et al., (1996b) on Florida red tilapia, Baras et al., (2001) on O. niloticus (strain Manzala), and Desprez and Melard (1998) on O. aureus, that high temperatures skewed the sex ratio in favor of males. On the other hand, we found that low rearing temperatures $\left(25^{\circ} \mathrm{C}\right)$ did not affect the sex ratio of progenies $\mathrm{C} 25 \mathrm{H}$, confirming results obtained for other strains and species of tilapia.

In $O$. niloticus, temperature influences on sex ratio have been detected that can (but not always) override the action of the sex determining genes (Abucay et al., 1999; Baras et al., 2001; Baroiller and D'Cotta, 2001). Temperature conditions are anticipated to have variable effects on sex differentiation depending on the height of temperature and the genetic background (Argue and Phelps, 1995). Desprez, and Melard (1998) reared tilapia fry O. aureus at $21^{\circ} \mathrm{C}\left(40\right.$ days), $27^{\circ} \mathrm{C}$ and $34^{\circ} \mathrm{C}(25$ days) then at $27^{\circ} \mathrm{C}$ and sexed. They found that, high temperature regimes produced high male ratios $(97.8 \%)$ while intermediate thermal regime gave balanced ratios (63.0\%). Low temperature delayed the differentiation of gonads. Also, Varadaraj et al. 1994 and Abucay (1997) reported that, the temperature as high as $36^{\circ} \mathrm{C}$ during hormone treatment can increase the rate of sex reversal.

The results presented here provide evidence of a significant effect of temperature on sex ratio in O. niloticus (in the direction to male), confirming results obtained for this and other tilapia species in previous studies (Mair et al., 1990; Mbahinzireki and Dabrowski, 1997 and Baras et al., 2001). The observed sensitivity of the fish used in these studies to high temperature is likely to be related to effects during sexual differentiation. There are two possible developmental pathways whereby temperature can affect this process. First, an environmental shock such as high temperature might disrupt the normal development processes during sex differentiation causing the switch to males for the genetic females and switch to females for the genetically male progeny. Second, the high temperature might have an effect on the structure or action of a hormone or hormones acting during sex differentiation (Hunter and Donaldson, 1983). For example, Wibbels et al., (1994) discuss the potential effects of temperatures on the action of aromatase the catalyst for the breakdown of androgens to estrogens.

All in all, the results obtained suggest that $O$. niloticus a thermo-sensitive specie and temperature can affect gonadal sex differentiation of the individuals during the early development stages.

The combined effect of rearing water temperature and 17 $\alpha$-MT treatment indicated a significant increase in male ratio compared to the effect of water temperature or $17 \alpha-\mathrm{MT}$ alone and these results showed the possibility of reducing hormone treatment period from 4 to 2 weeks by increasing rearing water temperature to 30 or $35^{\circ} \mathrm{C}$ with obtaining an appropriate male population (93.33 and $96.67 \%$, respectively) and this could be reduce hormone costs and its problems in producing sex reversal of $O$. niloticus fry. On the other hand, Drummond et al., (2009) found no significant interaction between temperatore $\left(26,28,30\right.$ and $\left.30^{\circ} \mathrm{C}\right)$ and hormonal doses $(0$, 20,40 and $60 \mathrm{mg} 17 \alpha-\mathrm{MTkg}$ diet) for sex ratio of $O$. niloticus fry used for sex reversal.

\section{Mortality rate:}

The first fish group (C25H0) after one week showed the lowest mortality rate of O. niloticus fry $(10.33 \%)$ which did not significantly different from $11.17 \%$ that obtained by the second fish group $(\mathrm{C} 25 \mathrm{H} 1)$ that reared at the same temperature $\left(25^{\circ} \mathrm{C}\right)$ and received 17 $\alpha-\mathrm{MT}$ and the same trend was also observed during the other treatment period (2, 3 and 4 weeks). Indicating that MT treatment did not significantly affected mortality rate of O. niloticus. Varadaraj (1990) found no significant differences $(\mathrm{P}>0.05)$ in mortality rate between treated and untreated O. mossambicus 
fry with 19-norethisterone acetate. Also, Cruz and Mair (1994), Goerrero III and Goerrero (1997) and Mainardes-Pinto et al., (2000), found that 17 $\alpha$-MT has little or no effect on the growth and survival of Nile tilapia during the hormonal treatment of O. niloticus fry.

On the other hand, Pandian and Sheela (1995) decided that, treatment involving a synthetic steroids result in higher mortality in three natural populations of $O$. niloticus. Cruz \& Mair (1994) mention that fry mortality observed during the hormonal treatment may be explained by the establishment of feed hierarchy among fish. Dominant individoals within the population may consume more food and grow faster leaving less food for submissive individuals who have less growth and become, consequently, vulnerable to cannibalism and death by starvation.

After one week from treatment the $3^{\text {rd }}$ fish group $(\mathrm{C} 30 \mathrm{H} 0)$ showed high mortality rate $(14.00 \%)$ which did not significantly different from $14.67,14.33$ and $14.00 \%$ that obtained for the other three fry groups $\mathrm{C} 30 \mathrm{H} 1, \mathrm{C} 35 \mathrm{H} 0$ and $\mathrm{C} 35 \mathrm{H} 1$, respectively. Similar results were obtained after 2, 3 and 4 weeks from treatment statr and this results may be attributed to the effect of high rearing water temperature (30 or $35^{\circ} \mathrm{C}$ ) compared to the normal rearing water temperature $25^{\circ} \mathrm{C}$ used in the first and second (C25H0 and $\mathrm{C} 25 \mathrm{H} 1)$ fish groups.

Supplementation of $O$. niloticus fry feed by $60 \mathrm{mg} 17 \alpha-\mathrm{MT} / \mathrm{kg}$ diet with increasing rearing water temperature to 30 or $35^{\circ} \mathrm{C}(\mathrm{C} 30 \mathrm{H} 1$ and $\mathrm{C} 35 \mathrm{H} 1)$ significantly increased mortality rate to 14.67 and $14.00 \%$ after one week; 16.00 and $15.67 \%$ after two weeks; 15.33 and $15.67 \%$ after three weeks and 16.00 and $17.33 \%$ after four weeks of treatment. In the same trend, increasing rearing water temperature to 30 or $35^{\circ} \mathrm{C}$ without $17 \alpha-\mathrm{MT}(\mathrm{C} 30 \mathrm{H} 0$ and $\mathrm{C} 35 \mathrm{H} 0)$ significantly increased mortality rate to 14.00 and $14.33 \%$ after one week; 15.33 and $15.00 \%$ after two weeks; 15.33 and $15.17 \%$ after three weeks and 15.83 and $16.83 \%$ after four weeks of treatment. These results are in agreement with those observed by Drummond et al., (2009) who found that, the values of survival (\%) of $O$. niloticus after 28 days of treatment there was significant interaction of temperatore $\left(26,28,30\right.$ and $\left.30^{\circ} \mathrm{C}\right)$ and hormonal doses $(0$, 20, 40 and $60 \mathrm{mg} 17 \alpha$-MTkg diet).

The obtained results in the present study (Table 4) showed that the graded increase in water temperature significantly increased mortality rate of O. niloticus fry specially at $35^{\circ} \mathrm{C}$ and this effect was cleared observed after 4 weeks of water temperature treatment whereas mortality rate reached to $17.33 \%(\mathrm{C} 35 \mathrm{H} 1)$ compared to $10.33 \%$ for control $(\mathrm{C} 25 \mathrm{H} 0)$ water temperature $\left(25^{\circ} \mathrm{C}\right)$.

Table 4: Mortality rate of $O$. niloticus fry in different water temperature and fed diet with or without $17 \alpha$-MT for four weeks

\begin{tabular}{|l|c|c|c|c|}
\hline \multirow{2}{*}{ Treatments } & \multicolumn{4}{|c|}{ Duration of treatments (week) } \\
\cline { 2 - 5 } & 1 & 2 & 3 & 4 \\
\hline $\mathrm{C} 25 \mathrm{H} 0$ & $10.33 \mathrm{c}$ & $10.33 \mathrm{c}$ & $10.33 \mathrm{c}$ & $10.33 \mathrm{~b}$ \\
\hline $\mathrm{C} 25 \mathrm{H} 1$ & $11.17 \mathrm{bc}$ & $12.50 \mathrm{~b}$ & $12.83 \mathrm{bc}$ & $12.00 \mathrm{~b}$ \\
\hline $\mathrm{C} 30 \mathrm{H} 0$ & $14.00 \mathrm{ab}$ & $15.33 \mathrm{a}$ & $15.33 \mathrm{ab}$ & $15.83 \mathrm{a}$ \\
\hline $\mathrm{C} 30 \mathrm{H} 1$ & $14.67 \mathrm{a}$ & $16.00 \mathrm{a}$ & $15.33 \mathrm{a}$ & $16.00 \mathrm{a}$ \\
\hline $\mathrm{C} 35 \mathrm{H} 0$ & $14.33 \mathrm{a}$ & $15.00 \mathrm{a}$ & $15.17 \mathrm{ab}$ & $16.83 \mathrm{a}$ \\
\hline $\mathrm{C} 35 \mathrm{H} 1$ & $14.00 \mathrm{ab}$ & $15.67 \mathrm{a}$ & $15.67 \mathrm{a}$ & $17.33 \mathrm{a}$ \\
\hline $\mathrm{SE}$ & \pm 0.97 & \pm 0.97 & \pm 0.97 & \pm 0.97 \\
\hline
\end{tabular}

Means followed by different letters in each column for each treat for each trait significantly different $(\mathrm{P}<0.05)$.

This suggests that the period of metamorphosis, including change in the style of energy-uptake from yolk to exogenous nutrition, is susceptible to damage resulting 
from abrupt temperature changes. Similar results were also obtained by Baras et al., (2001). In this respect, Azaza et al., (2008) found that the best rate of masculizing $(80 \%)$ was obtained after exposure to $36.83^{\circ} \mathrm{C}$, but with lower survival rates during treatment (60\%).Borges et al., (2005) observed that with increasing temperatore survival rates of tilapia are directly related with the occurrence of cannibalism, significantly higher at $35^{\circ} \mathrm{C}$.

\section{Fry body weight (BW):}

At all treatment periods $(1,2,3$ or 4 weeks) results indicated that, the highest BW averages were recorded for fry group administrated $60 \mathrm{mg} 17 \alpha-\mathrm{MT} / \mathrm{kg}$ feed and reared at water temperature of $35^{\circ} \mathrm{C} \mathrm{C} 35 \mathrm{H} 0$ which did not significantly different from those recorded in $\mathrm{C} 30 \mathrm{H} 1$ group and the opposite trend was observed with control fry group which did not received $17 \alpha-\mathrm{MT}$ and reared at the lower water temperature $(\mathrm{C} 25 \mathrm{H} 0)$ and these results may be attributed to the high male percent related to the high rearing water temperature and 17 $\alpha$-MT (Table 5).

Table 5: Body weight of $O$. niloticus fry in different water temperature and fed diet with or without $17 \alpha$-MT for four weeks

\begin{tabular}{|l|c|c|c|c|}
\hline \multirow{2}{*}{ Treatments } & \multicolumn{4}{|c|}{ Duration of treatments (week) } \\
\cline { 2 - 5 } & 1 & 2 & 3 & 4 \\
\hline $\mathrm{C} 25 \mathrm{H} 0$ & $0.12 \mathrm{~d}$ & $0.23 \mathrm{c}$ & $0.56 \mathrm{~d}$ & $1.02 \mathrm{f}$ \\
\hline $\mathrm{C} 25 \mathrm{H} 1$ & $0.20 \mathrm{c}$ & $0.37 \mathrm{~b}$ & $0.81 \mathrm{c}$ & $1.59 \mathrm{e}$ \\
\hline $\mathrm{C} 30 \mathrm{H} 0$ & $0.25 \mathrm{~b}$ & $0.45 \mathrm{ab}$ & $1.07 \mathrm{~b}$ & $1.75 \mathrm{~d}$ \\
\hline $\mathrm{C} 30 \mathrm{H} 1$ & $0.29 \mathrm{ab}$ & $0.49 \mathrm{a}$ & $1.12 \mathrm{~b}$ & $1.95 \mathrm{c}$ \\
\hline $\mathrm{C} 35 \mathrm{H} 0$ & $0.28 \mathrm{ab}$ & $0.47 \mathrm{a}$ & $1.32 \mathrm{a}$ & $2.07 \mathrm{~b}$ \\
\hline $\mathrm{C} 35 \mathrm{H} 1$ & $0.31 \mathrm{a}$ & $0.51 \mathrm{a}$ & $1.34 \mathrm{a}$ & $2.27 \mathrm{a}$ \\
\hline $\mathrm{SE}$ & \pm 0.012 & \pm 0.032 & \pm 0.051 & \pm 0.032 \\
\hline
\end{tabular}

Means followed by different letters in each column for each treat for each trait significantly different $(\mathrm{P}<0.05)$.

Our ressults are in agreement with many previous studies. Drummond et al., (2009) found a significant interaction between temperatore $\left(26,28,30\right.$ and $\left.30^{\circ} \mathrm{C}\right)$ and hormonal doses $(0,20,40$ and $60 \mathrm{mg} 17 \alpha$-MTkg diet) for weight gain of $O$. niloticus fry used for sex reversal ( $\mathrm{p}<0.01)$. Macintosh et al., (1985) indicated that, there were significant differences between hormone treated and untreated tilapia fry. They obtained an average weight increase of $64 \%$ over control when feeding $O$. mossambicus fry with MT-30 mg for 60 days. Also, McAndrew and Majumdar (1989) obtained a $25.7 \%$ increase in BW over controls when $O$. niloticus fry were treated with MT-40 for 40 days. Varadaraj (1990) indicated that, the increase in BW of $O$. mossambicus fry treated with 19-norethisterone acetate than control for 15 days may be attributed to the anabolic effect of 19-NE on metabolism. Khater (1999) indicated that, O. niloticus fry treated with $17 \alpha-\mathrm{MT}$ had significantly $(\mathrm{P}<0.05)$ higher $\mathrm{BW}$ as compared to the control group (received no hormone in the diet) after 14, 21 and 28 days of $17 \alpha-$ MT treatment. Also, Khalil et al., (2011) and Beaven and Muposhi (2012) found that $O$. niloticus fry fed to a diet treated with MT had a significantly higher growth and body weight as compared to those fed to a non hormone treated diet.

\section{REFERENCES}

Abucay, J. S. (1997). Genetic and environmental factors affecting growth and sex ratio in the Nile tilapia، Oreochromis niloticus L. Ph.D Thesis. University of Wales Swansea, $326 \mathrm{pp}$. 
Abucay, J. S., Mair, G. C., Skibinski, D. O. and Beardmore, J. A. (1999). Environmental sex determination: the effect of temperature and salinity on sex ratio in Oreochromis niloticus L. Aquaculture, 173:219-234.

Argue, B.J. and Phelps, R.P., (1995). Temperature effect on sex ratios in Oreochromis niloticus. J. Appl. Ichthyol., 11:126-128.

Azaza, M. S., Dhra'ief, M.N. and Kra'iem, M. M. (2008). Effects of water temperature on growth and sex ratio of juvenile Nile tilapia Oreochromis niloticus (Linnaeus) reared in geothermal waters in southern Tunisia. J. of Therm. Biolo., 33:98-105

Balarin, J.D. and Hatton, J.P. (1979). Tilapia. A Guide to Their Biology and Culture in Africa. Unit of Aquatic Pathobiology, University of Stirling, Scotland.

Baras, E., Jacobs, B. and Melard, C. (2001). Effect of water temperature on survival, growth and phenotypic sex of mixed (XX-XY) progenies of Nile tilapia Oreochromis niloticus. Aquaculture 192:187-199.

Baras, E., Prignon, C., Gohoungo, G. and Melard, C. (2000). Phenotypic sex differentiation of blue tilapia under constant and fluctuating thermal regimes and its adaptive and evolutionary implications. J. Fish Biol. 57:210-223.

Baroiller, J.F., Chourrout, D., Fostier, A., Jalabert, B., (1995). Temperature and sex chromosomes govern sex ratios of the mouthbrooding Cichlid fish Oreochromis niloticus. J. Exp. Zool. 273, 216-223.

Baroiller, J.F., Fostier, A., Cauty, C., Rognon, X., Jalabert, B., (1996a). Effect of high rearing temperature on the sex ratio of progeny from sexreversed males of Oreochromis niloticus. In: Pullin, R.S.V., Lazard, J., Legendre, M., Amon kothias, J.B., Pauly, D. (Eds.), Proceedings of the Third Symposium on tilapia in Aquaculture. ICLARM Conference Proceedings, 41, pp. 246-256.

Baroiller, J.F., Clota, F., Geraz, E., (1996b). Temperature sex determination in two tilapias species, Oreochromis niloticus and the red tilapia (Red Florida strain): effect of high or low temperatures. In: Goetz, F., Thomas, P. (Eds.), Proceeding of the Fifth International Symposium on the Reproductive Physiology of Fish, Austin, TX, pp. 158-160.

Baroiller, J. F.and D'Cotta, H. (2001). Environment and sex determination in farmed fish. Comp. Biochem. Physiol. 130: 399-409.

Beaven, U. and Muposhi, V. (2012). Aspects of a Monosex Population of Oreochromis Niloticus Fingerlings Produced Using 17-a Methyl Testosterone Hormone. J Aquacult Res Dev 3:132-137

Borges, A. M.; Moretti, J. O. C.; McManus, C.; Mariante, A. S. (2005). Produção de populações monossexo macho de tilápia-do-nilo da linhagem Chitralada. Pesquisa Agropecuária Brasileira, Brasília., 40(2): 153-159.

Clark, G. (1981): Staining Procedures, 4th ed, 1981, pp15.

Cruz, E. M. V. and Mair, G. C. (1994). Conditions for effective androgen sex reversal in Oreochromis niloticus (L). Aquacult.,122:237-248.

Desprez, D. and Melard, C. (1998). Effect of ambient water temperature on sex determinism in the blue tilapia Oreochromis aureus. Aquacult., 162:79-84.

Drummond, C. D., Murgas, L. D. and Vicentini, B. (2009). Growth and survival of tilapia Oreochromis niloticus (Linnaeus, 1758) submitted to different temperatures during the process of sex reversal. Cienc. agrotec., Lavras, 33(3):895-902.

Duncan, M. B. (1955). Multiple ranges and multiple F-tests. Biometrics, 11:1-42.

Guerrero III R. D. (1982). Control of tilapia reproduction: In RSV Pullin, RH Lowe McConnell, eds. The Biology and Culture of Tilapias. ICLARM Conference 
Proceedings 7. International Center for Living Resources Management, Manila, Philippines, 309-316.

Guerrero III R.D. and Guerrero, L.A. (1997). Effects of Androstenedione and methyltestosterone on Oreochromis niloticus fry treated for sex reversal in ootdoor net enclosore. In: International Sypmosium on tilapia in aquaculture,4., 1997, Orlando, Florida. Proceedings. Orlando, 2: 772-777.

Guerrero III R.D. and Guerrero, L.A. (1988). Feasibility of commercial production of Nile tilapia fingerlings in Philippines: In RSV Pullin, T Bhukaswan, K Tonguthai, JL Maclean, eds. The Second International Symposium on Tilapia in Aquacul-ture. ICLARM Conference Proceedings 15, Department of Fisheries, Bangkok, Thailand, and International Center for Living Aquatic Resources Management, Manila, Philippines, 183-186.

Guerrero, R.D. and Shelton, W.L. (1974). An aceto-carmine squash method for sexing juvenile fishes. The Progressive Fish-Culturist 36, 56.

Hickling, C. F. (1960). The Malacca tilapia hybrids. Journal of Genetics 57: 1-10.

Hunter G. A. and Donaldson, E. M. (1983). Hormonal sex control and its application to fish culture. In: Fish Physiology (ed. by W. S. Hoar, D. J. Randall \& E. M. Donaldson), Vol. 1X B, pp. 223-303. Academic Press, New York.

Khalil, W. K., Wafaa S. Hasheesh, Marie, M. A., Abbas, H. H. and Eman A. Zahran (2011). Assessment the impact of 17a-methyltestosterone hormone on growth, hormone concentration, molecular and histopathological changes in muscles and testis of Nile tilapia, Oreoehromis nilotieus. Life Science J., 8(3):329-343.

Khater, A. M. M. (1999). Sex reversal in tilapia nilotica. Ph.D Thesis, Faculty of Agriculture, Zagazig University.

Killian, H. S. and Kohler, C. C. (1991). Influence of $17 \alpha$-methyltestosterone one on Red Tilapia under two thermal regime. J. World. Aquacult. Soc., 22 (2): 83- 94.

Macintosh, D. L., Varghese, T. J. and Satyanarayana Rao, G. P. (1985). Hormonal sex reversal of wild spawned tilapia in India. J. Fish Biol., 26:87-94.

Mainardes-Pinto, C. S. R.; Fenerich-Verani, N.; Campos, B. E. S.; Silva, A. L. (2000). Mascolinizacao da Tilapia do Nilo, Oreochromis niloticus, otilizando diferentes racoes diferentes doses de 17?-metiltestosterona. Revista Brasileira de Zootecnia, Vicosa, 29(3):654-659.

Mair, G. C., Beardmore, J. A. and Skibinski, D.O.F. (1990). Experimental evidence for environmental sex determination on Oreochromis species. In: Hirano, R., Hanyu, I. Eds., The Second Asian Fisheries Forum. Asian Fisheries Society. Manila, Philippines, $991 \mathrm{pp}$.

Mbahinzireki, G. and Dabrowski, K. (1997). Production of male tilapia by heattreatment of embryos and growth of different diets in recirculating systems. Paper presented during the World Aquaculture Society Conference held at Washington State Convention Center, Seattle, WA, USA, 19-23 February 1997.

McAndrew, B. J. and Majumdar, K. C. (1989). Growth studies on juvenile tilapia using pure species. Hormone treated and nine interspecific hybrids. Aqua. And Fish Manag., 20:35-47.

Melard, C., (1986). Les bases biologiques de l'elevage du tilapia du Nil. Cah. Ethol. Appl. 6:1-224.

Pandian, T. J. and Sheela, S. G. (1995). Hormonal induction of sex reversal in fish. Aquaculture, 138:1-22.

Pandian, T. J. abd Varadaraj, K. (1988). Techniques for producing all male and all-triploid Oreochromis mossambicus: In RSV Pullin, T Bhukaswan, K Tonguthai, JL Maclean, eds. The Second International Symposium on Tilapia in Aquacul-ture. 
ICLARM Conference Proceedings 15. Department of Fisheries, Bangkok, Thailand, and International Center for Living Aquatic Resources Management, Manila, Philippines, 243-249.

SAS (1996). SAS Procedure Guide "version 6.12 Ed". SAS Institute Inc., Cary, NC, USA.

Tessema, M. Müller-Belecke, A. and Gabriele Hörstgen-Schwark (2006). Effect of rearing temperatures on the sex ratios of Oreochromis niloticus populations. Aquaculture, 258:270-277

Trewavas, E. (1983). Tilapiine Fishes of the Genera Sarotherodon, Oreochromis and Danakilia. British Museum (Natural History), London.

Varadaraj, K. (1990). Production of monosex male Oreochromis mossambicus (Peters) by administering 19-norethisterone acetate. Aquaculture and Fisheries Management 21:133-135.

Varadaraj, K., Kumari, S. S. and Pandian, T.J. (1994). Comparison of conditions for hormonal sex reversal of Mozambique Tilapias. The Prog. Fish Cult. 56:81-90.

Wibbels, T., Bull, J. J. and Crews, D. (1994). Temperature-dependant sex determination: a mechanistic approach. Journal of Experimental Zoology, 270: $71-78$

\section{ARABIC SUMMARY}

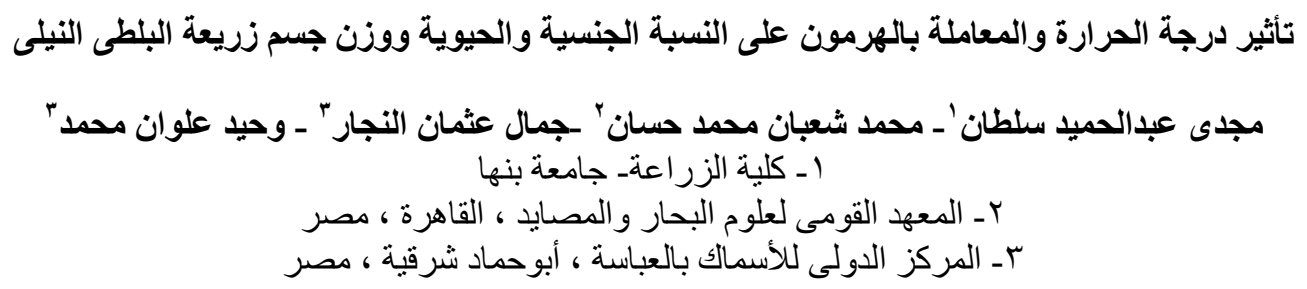

أجريت هذه التجربة بهذف معرفة تأثير درجة حرارة الماء مع أو بدون هرمون الذكوره (V) ألفاب ألفا ميثايل

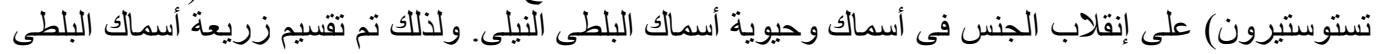

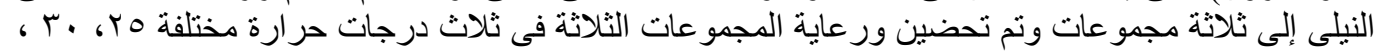

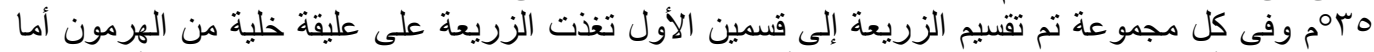

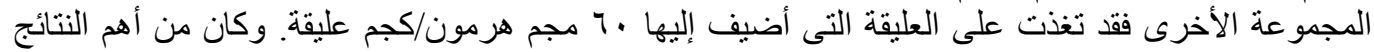

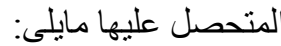

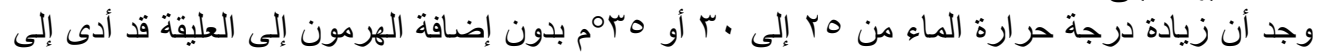
زيادة نسبة الذكور من زيادة

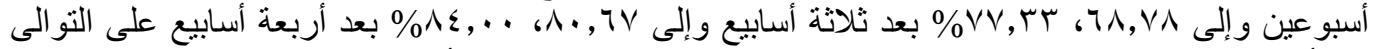

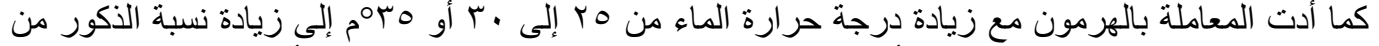

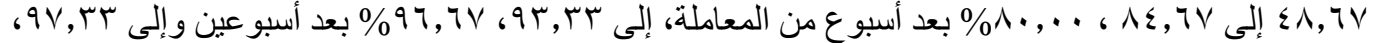

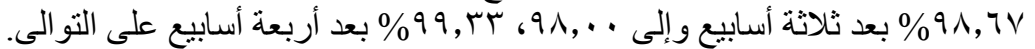

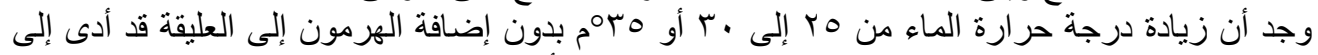

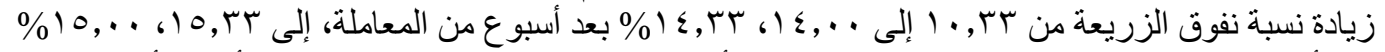

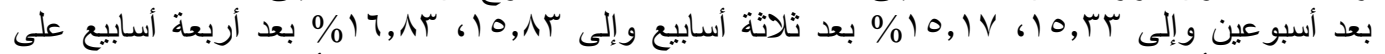

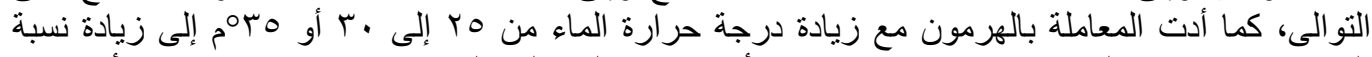

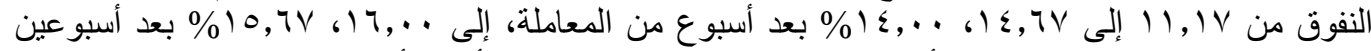

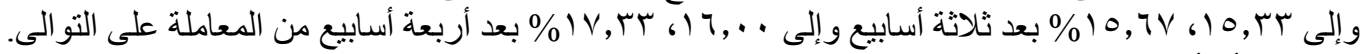

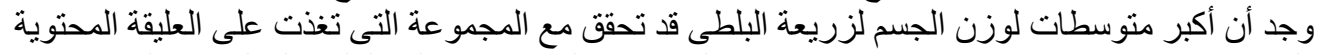

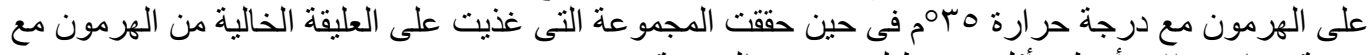

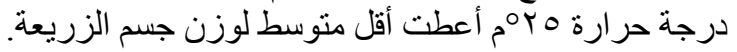

